\title{
The influence of shell species and size on the shell selection pattern of Paguristes tortugae (Decapoda, Diogenidae) from Anchieta Island (Ubatuba, Brazil)
}

\author{
Laura C. C. Dominciano ${ }^{1,2}$ \& Fernando L. M. Mantelatto ${ }^{1}$ \\ 1. Laboratório de Bioecologia e Sistemática de Crustáceos, Departamento de Biologia, Faculdade de Filosofia, Ciências e Letras
de Ribeirão Preto (FFCLRP), Universidade de São Paulo (USP), Av. Bandeirantes, 3900, 14040-901 Ribeirão Preto, SP, Brasil.
(flmantel@usp.br) \\ 2. Curso de Pós-Graduação em Ciências, Área: Biologia Comparada.
}

\begin{abstract}
Shell selection by the hermit crab Paguristes tortugae Schmitt, 1933 from Anchieta Island (Brazil) was analyzed using the six most frequently occupied shell species in the field and taking into account the sexual condition of the individuals, the shell size and the shell species. The experiments were conducted under laboratory conditions and the shell species preference was estimated on the basis of the frequency that each species was chosen by the individuals. The preferred shell species and size were determined by regression analysis. The highest correlation coefficients were obtained for the relations between the hermit dimensions and shell dry weight. The ovigerous females preferred shells with larger internal volume: Leucozonia nassa (Gmelin, 1791) and Cerithium atratum (Born, 1778). In the experiment of shell size, males preferred heavier shells whereas females selected the shape characteristics of the shell, such as the aperture and the internal volume, which are probably related to the growth and offspring guarantee, respectively. In general, and independent of sex condition, P. tortugae showed significant selection among all shells utilized. The results suggest that shell selection by $P$. tortugae involves sexual and reproductive condition preferences.
\end{abstract}

KEYWORDS. Anomura, hermit crab, shell preference, Paguristes.

\section{INTRODUCTION}

According to ReESE (1962), the hermit crabs may distinguish shells of various species and also recognize a prior occupation. They can discriminate the weight of shells of the same species, as well as their form, cover and dimension, possibly selecting adequate shells with proper weight (MARTINELLI \& MANTELATTO, 1999).

During the last three decades, shell selection process has been well investigated (GARCia \& Mantelatto, 2001), especially with regard to the interesting and sometimes unclear mechanism developed by hermit crabs. Considering the large number (46) of hermit crab species recorded in Brazilian waters (Melo, 1999; MantelatTo et al., 2001), studies on shell selection behavior involving field and laboratory comparative observations have not been developed, except for Calcinus tibicen (Herbst, 1791) in Ubatuba region, São Paulo State (Garcia \& Mantelatto, 2001). The genus Paguristes Dana, 1852, represented by more than 100 species distributed in all tropical and subtropical oceans (Provenzano, 1978), has been a particularly difficult group to study (MANTElatto et al., 2002).

Paguristes tortugae Schmitt, 1933 has been found occupying 21 gastropod shell species in Ubatuba region, demonstrating plasticity in shell species utilization and a clear competitive ability among individuals of different sizes in the population (MANTELATTO \& DominCIANo, 2002). Considering that previous studies have suggested that hermit crab shell preferences are important in mediating the shell utilization patterns found in natural populations (Fotheringham, 1976; Bertness, 1980; Elwood \& Neil, 1992; Siu \& Lee, 1992; Ohmori et al., 1995; Garcia \& Mantelatto, 2001), the present work aimed to evaluate the size and shell species preferences of males and females of $P$. tortugae from Anchieta Island as part of a long-term study undertaken to identify the most important parameters of shell occupation and shell selection by coexisting hermit crab species in a subtropical rocky intertidal area, through both laboratory and field observations.

\section{MATERIAL AND METHODS}

A series of laboratory experiments were performed to study the pattern of shell utilization and to confirm experimentally the field observations (MANTELATTO \& Dominciano, 2002). Shell species and size preferences of the hermit crabs were determined for the six most used shells in the field: Pisania auritula (Link, 1807), Cerithium atratum (Born, 1778), Morula nodulosa (C. B. Adams, 1845), Leucozonia nassa (Gmelin, 1791), Tegula viridula (Gmelin, 1791) and Stramonita haemastoma (Linnaeus, 1767), according to the methods described by Bertness (1980), Siu \& LeE (1992), OhMORi et al. (1995), Hazlett (1996) and Garcia \& Mantelatto (2001).

Specimens were collected between February 2000 and March 2001 from infralittoral rocky/sandy areas of Anchieta Island, Ubatuba, Southern Brazil by SCUBA. Details of the methods of capture and study area can be found in Mantelatto \& Dominciano (2002) and MANTELATTO \& Garcia (2002). All shell-selection tests were conducted in the laboratory. The size of crabs tested was checked and then experiments were performed using a set of shells that involved appropriate sizes for crabs. The hermit crabs were placed naked with a larger number of shells of appropriate sizes inside a glass aquarium (30 $\mathrm{x} 30 \mathrm{x} 40 \mathrm{~cm}$ ) with aerated seawater, and bottom compound 
of crashed shells and medium sand. Each animal was used only once in order to avoid any acquired behavior. After the experiments, some animals were returned to the field and others were deposited as vouchers at the Coleção de Crustáceos do Departamento de Biologia da Faculdade de Filosofia, Ciências e Letras de Ribeirão Preto (FFCLRP), Universidade de São Paulo (USP). The animals that died during the experiments were not included in the analysis.

Shell species preference. All experiments were conducted in a pair-wise fashion. For each test, hermit crabs $(\mathrm{N}=15)$ were placed naked in the aquarium with a minimum of 150 empty shells (10 shells for each hermit crab; $50 \%$ of each shell species). The size (shield length) of hermit crabs ranged from $1.7-7.2 \mathrm{~mm}$ (males), $1.6-6.0 \mathrm{~mm}$ (non-ovigerous females), and $2.1-6.4 \mathrm{~mm}$ (ovigerous females). The size (aperture width) of shells ranged from $1.3-6.9 \mathrm{~mm}$ (Cerithium atratum), 1.3 - $5.3 \mathrm{~mm}$ (Morula nodulosa), $1.4-10.3 \mathrm{~mm}$ (Leucosonia nassa), 1.7 - $13.8 \mathrm{~mm}$ (Pisania auritula), $3.9-13.0 \mathrm{~mm}$ (Stramonita haemastoma), and $4.5-15.0 \mathrm{~mm}$ (Tegula viridula). Individuals (hermit and shells) of almost all sizes were tested considering adequate sizes between both and based on information from field data (Mantelatto \& Dominciano, 2002). Each test was performed four times. Males and females were tested in similar proportions during the experiments.

After $72 \mathrm{~h}$ (a period of time established on the basis of previous experiments, when more than $80 \%$ of the individuals analyzed stopped changing shells), the hermit crabs were removed from their chosen shells by heating the shells in water at $\sim 100^{\circ} \mathrm{C}$ (GARCiA \& MANTELATTO, 2001). Each hermit crab was weighed $(\mathrm{WW}=$ Wet Weight $)$ and measured for shield length (SL), and had its sex checked. The species of the chosen shells were identified and their aperture width (SAW), internal volume (SIV) and dry weight (SDW) were determined.

The shell species preference was estimated on the basis of the frequency with which each species was chosen by the individuals ( $x^{2}$ - chi-square test; ZAR, 1996) and the morphometric relationships were established by regression analysis and correlation coefficients $(\mathrm{r})(\mathrm{P}<$ 0.05) performed with SigmaStat Statistical Software v. 2.0.

The shells of $C$. atratum and $M$. nodulosa were not compared with other species during this experiment because these shells are smaller than the others and were occupied only by small individuals $(1.1-4.7 \mathrm{~mm} \mathrm{SL})$.

The experiments were not performed separately in relation to the sex of individuals because we assumed that the presence of males and females in each test would be important to avoid effects related to hierarchy behavior, i.e., males are hierarchically superior to females and their absence could lead the females to some behavior different from that observed if males were present and, besides both sexes are found grouped in the wild (GARCIA \& Mantelatto, 2001).

Shell size preference. The experiments were conducted for each of the six shell species. In each test, 15 hermit crabs were placed naked in the aquarium with about 150 empty shells ( 10 shells for each hermit crab) of the same species and of adequate size. Four replicates of each test were done. After $72 \mathrm{~h}$, the hermit crabs were removed from their chosen shells by the same method as above and measured as described for the shell species experiments.

Results of the tests were analyzed using the following regression for each shell type: $\log \mathrm{Y}=\mathrm{a}+\mathrm{b} \log$ $\mathrm{X}$ (where $\mathrm{Y}=$ shell measurements: SAW, SIV, SDW and $\mathrm{X}$ $=$ hermit crab measurements: SL and $\mathrm{WW}$ ). It was established an equation that reflected the species and size of shells more adequate to the hermit crabs under study, established by significance analysis of correlation coefficients ( $\mathrm{P}<0.05$; ZAR, 1996).

\section{RESULTS AND DISCUSSION}

A total of 403 animals were utilized (176 males, 137 non-ovigerous females and 90 ovigerous females) in the experiments of shell species preference. Males and females of $P$. tortugae showed different preferences for one of the two shell species offered during pair-wise experiments (tab. I). The order of shell species preference was $L$. nassa $>P$. auritula $>S$. haemastoma $>$. viridula for larger individuals and C. atratum $>M$. nodulosa for smaller ones.

On the experiments of shell size preference 340 animals were utilized ( 145 males, 140 non-ovigerous females and 55 ovigerous females). Shell size experiments revealed that the hermit crabs' preference was significant in all relations analyzed to L. nassa and S. haemastoma. The hermit crabs showed strong association with shell weight and aperture width of $L$. nassa and $S$. haemastoma. In general the best correlations occurred between weight of hermit crab and shell weight and internal volume. The other shell species showed lower coefficients $(\mathrm{P}<0.05)$ (tab. II).

The shell choice of males, ovigerous females and nonovigerous females showed different patterns for each shell

Table I. Shell species preference of Paguristes tortugae among the six most frequently occupied shells in the infralittoral rocky/sandy areas of Anchieta Island, Ubatuba, São Paulo ( $\mathrm{c}^{2}$ - test value, in brackets; $\mathrm{n} / \mathrm{n}$, number of occurrence of the shell species chosen by the individuals; ns, not significant; ${ }^{*}$, significant value, $\left.\mathrm{P}<0.05\right)$.

\begin{tabular}{|c|c|c|c|c|}
\hline Species 1 versus species 2 & Males & $\begin{array}{c}\text { Non-ovigerous } \\
\text { females }\end{array}$ & $\begin{array}{c}\text { Ovigerous } \\
\text { females }\end{array}$ & Total \\
\hline Cerithium atratum / Morula nodulosa & $21 / 1(18.18 *)$ & $22 / 4\left(12.46^{*}\right)$ & $7 / 1(4.50 *)$ & $50 * / 6(34.57 *)$ \\
\hline Pisana auritula / Stramonita haemastoma & $13 / 12(\mathrm{~ns})$ & $15 / 6(7.14 *)$ & $12 / 2(3.86 *)$ & $40 * / 20(6.67 *)$ \\
\hline Pisana auritula / Tegula viridula & $25 / 4\left(15.21^{*}\right)$ & $16 / 2(10.89 *)$ & $10 / 0(10.00 *)$ & $51 * / 6(35.53 *)$ \\
\hline Pisana auritula / Leucozonia nassa & $5 / 18(7.35 *)$ & $5 / 12$ (ns) & $6 / 12(\mathrm{~ns})$ & $16 / 42 *(11.66 *)$ \\
\hline Leucozonia nassa / Stramonita haemastoma & $19 / 9(\mathrm{~ns})$ & $17 / 0(17.00 *)$ & $16 / 1(13.24 *)$ & $50 * / 10(26.67 *)$ \\
\hline Leucozonia nassa / Tegula viridula & $16 / 1\left(13.24^{*}\right)$ & $19 / 2\left(13.76^{*}\right)$ & $17 / 0(17.00 *)$ & $52 * / 3(43.65 *)$ \\
\hline Stramonita haemastoma / Tegula viridula & $23 / 9(6.13 *)$ & $13 / 4\left(4.76^{*}\right)$ & $8 / 0(8.00 *)$ & $44 * / 13(16.86 *)$ \\
\hline
\end{tabular}


Table II. Regression equations for each shell size chosen by Paguristes tortugae (r, correlation coefficient; SAW, shell aperture width; SDW, shell dry weight; SIV, shell internal volume; SL, shield length; WW, hermit wet weight; *, significant correlation, $\mathrm{P}<0.05$ ).

\begin{tabular}{|c|c|c|c|c|}
\hline Species & $\mathrm{n}$ & Relation & $\begin{array}{l}\text { Linear equation } \\
\log \mathrm{Y}=\mathrm{a}+\mathrm{b} \log \mathrm{X}\end{array}$ & $\mathrm{r}$ \\
\hline \multirow[t]{6}{*}{ Pisana auritula } & 59 & SIV x SL & $\operatorname{logSIV}=-1.83+0.94 \log \mathrm{SL}$ & $0.41 *$ \\
\hline & 59 & SAW x SL & $\log \mathrm{SAW}=1.17+0.36 \log \mathrm{SL}$ & $0.41 *$ \\
\hline & 59 & SDW x SL & $\operatorname{logSDW}=0.37+0.57 \operatorname{logSL}$ & $0.47 *$ \\
\hline & 59 & SIV $x$ WW & $\log \mathrm{SIV}=0.01+0.32 \log \mathrm{WW}$ & $0.42 *$ \\
\hline & 59 & SAW x WW & $\log \mathrm{SAW}=1.81+0.07 \log \mathrm{WW}$ & 0.25 \\
\hline & 59 & SDW x WW & $\operatorname{logSDW}=1.49+0.19 \log W W$ & $0.47 *$ \\
\hline \multirow[t]{6}{*}{ Cerithium atratum } & 46 & SIV x SL & $\log \mathrm{SIV}=-1.66+0.57 \log \mathrm{SL}$ & $0.43 *$ \\
\hline & 56 & SAW x SL & $\operatorname{logSAW}=1.42+0.14 \operatorname{logSL}$ & 0.25 \\
\hline & 56 & SDW x SL & $\operatorname{logSDW}=-0.69+0.40 \operatorname{logSL}$ & 0.25 \\
\hline & 46 & SIV $x$ WW & $\operatorname{logSIV}=-0.40+0.27 \log \mathrm{WW}$ & $0.36 *$ \\
\hline & 56 & SAW x WW & $\operatorname{logSAW}=1.94+0.16 \log W W$ & $0.46^{*}$ \\
\hline & 56 & SDW x WW & $\log \mathrm{SDW}=0.37+0.27 \log \mathrm{WW}$ & $0.28 *$ \\
\hline \multirow[t]{6}{*}{ Morula nodulosa } & 50 & SIV $x$ SL & $\operatorname{logSIV}=-2.66+0.58 \operatorname{logSL}$ & $0.42 *$ \\
\hline & 53 & SAW x SL & $\operatorname{logSAW}=0.89+0.29 \operatorname{logSL}$ & $0.37 *$ \\
\hline & 53 & SDW x SL & $\operatorname{logSDW}=-0.15-0.01 \log \mathrm{SL}$ & 0.10 \\
\hline & 50 & SIV x WW & $\operatorname{logSIV}=-2.53-0.15 \log \mathrm{WW}$ & 0.17 \\
\hline & 53 & SAW x WW & $\log \mathrm{SAW}=0.97-0.09 \log \mathrm{WW}$ & 0.22 \\
\hline & 53 & SDW x WW & $\operatorname{logSDW}=0.07+0.10 \log W W$ & 0.14 \\
\hline \multirow[t]{6}{*}{ Tegula viridula } & 57 & SIV x SL & $\operatorname{logSIV}=-0.89+0.51 \operatorname{logSL}$ & 0.20 \\
\hline & 57 & SAW x SL & $\log \mathrm{SAW}=2.24+0.11 \operatorname{logSL}$ & 0.25 \\
\hline & 57 & SDW x SL & $\operatorname{logSDW}=0.43+0.53 \operatorname{logSL}$ & $0.32 *$ \\
\hline & 57 & SIV $x$ WW & $\log \mathrm{SIV}=0.27+0.31 \log \mathrm{WW}$ & $0.37 *$ \\
\hline & 57 & SAW x WW & $\operatorname{logSAW}=2.48+0.07 \log \mathrm{WW}$ & $0.45 *$ \\
\hline & 57 & SDW x WW & $\operatorname{logSDW}=1.56+0.27 \log W W$ & $0.47 *$ \\
\hline \multirow{6}{*}{ Leucozonia nassa } & 49 & SIV x SL & $\log \mathrm{SIV}=-2.53+1.40 \log \mathrm{SL}$ & $0.65 *$ \\
\hline & 55 & SAW x SL & $\operatorname{logSAW}=1.12+0.48 \operatorname{logSL}$ & $0.67 *$ \\
\hline & 55 & SDW x SL & $\operatorname{logSDW}=-0.92+1.33 \operatorname{logSL}$ & $0.67 *$ \\
\hline & 49 & SIV $x$ WW & $\operatorname{logSIV}=0.25+0.47 \log \mathrm{WW}$ & $0.64 *$ \\
\hline & 55 & SAW x WW & $\operatorname{logSAW}=2.10+0.17 \log W W$ & $0.68 *$ \\
\hline & 55 & SDW x WW & $\operatorname{logSDW}=1.72+0.45 \log W W$ & $0.68 *$ \\
\hline \multirow{6}{*}{ Stramonita haemastoma } & 57 & SIV x SL & $\operatorname{logSIV}=-3.22+1.86 \log \mathrm{SL}$ & $0.58 *$ \\
\hline & 60 & SAW x SL & $\operatorname{logSAW}=1.28+0.47 \log \mathrm{SL}$ & $0.42 *$ \\
\hline & 60 & SDW x SL & $\operatorname{logSDW}=-0.89+1.36 \operatorname{logSL}$ & $0.54 *$ \\
\hline & 57 & SIV x WW & $\operatorname{logSIV}=0.61+0.70 \log \mathrm{WW}$ & $0.69 *$ \\
\hline & 60 & SAW x WW & $\log \mathrm{SAW}=2.23+0.18 \log \mathrm{WW}$ & $0.52 *$ \\
\hline & 57 & SDW $x$ WW & $\operatorname{logSDW}=1.87+0.53 \log \mathrm{WW}$ & $0.67 *$ \\
\hline
\end{tabular}

species. Males that preferred M. nodulosa showed significant correlation with the internal volume and aperture width of shells, while non-ovigerous females showed significant correlation only with shell internal volume. Males presented significant correlations in all morphometric relations evaluated to Leucozonia nassa and $S$. haemastoma. In contrast, males and non-ovigerous females showed significant correlations only in few relations with $P$. auritula. Only non-ovigerous females presented significant correlation with the dimensions of C. atratum. In T. viridula, only males showed significant correlation. Non-ovigerous and ovigerous females showed different patterns between the dimensions of $S$. haemastoma.

The smaller individuals of $P$. tortugae showed a clear preference for $C$. atratum. This shell species has a larger internal volume compared to $M$. nodulosa, which is smaller and has spiral nodose ribs and strait aperture (RIos, 1994). This choice may be related to the fact that small hermit crabs occupy larger shells to allow their future growth. According to REDDY \& BISEWAR (1993), the aperture size, weight and shell internal volume are important correlates of the choice of shells.

In relation to larger size shells, the species more available and more occupied in the field (P. auritula) showed better correlation with the hermit crabs and also were preferred in laboratory by P. tortugae. Leucozonia nassa has angular returns (RIos, 1994) and its architecture provides lightness, larger internal volume and larger aperture size when compared to $P$. auritula (spiral well-developed, heavier, with minor internal volume and aperture). The larger and heavier males (MANTELATTO \& Sousa, 2000) preferred L. nassa because of its architecture. Females (ovigerous and nonovigerous) did not show this significant preference, probably because the shells of both L. nassa and P. auritula are adequate to females' occupation.

According to BLACKSTONE (1984), hermit crabs show preference for shells previously occupied in the field, and the utilization and preference is a function of the shell availability. This pattern presents variability according to the adaptations of hermit crabs in the field. GARCIA \& Mantelatto (2001) showed that Calcinus tibicen did not present significant preference for shells under laboratory conditions when compared to shells utilized in the field. Paguristes tortugae showed a clear preference for shell species occupied in the field, compared to the high plasticity of shell occupation in Anchieta Island (Mantelatto \& Dominciano, 2002). A similar pattern of shell selection according to field occupancy and differences in shell species selection between sexes was found in Pagurus brevidactylus (Stimpson, 1859) in the same area (Andrea Meireles, pers. comm.)

In relation to sex, the ovigerous females preferred $P$. auritula and L. nassa instead of S. haemastoma, what was probably related to egg protection. According to 
Mantelatto et al. (2002), the fecundity was significantly higher in ovigerous females occupying heavier shells and, in relation to the shell species, it was verified that the fecundity of the ovigerous females in $P$. auritula and $L$. nassa shells (the larger ones) was not significantly different, as well as that of the ovigerous females occupying C. atratum and $M$. nodulosa shells. Also, the number of eggs produced by ovigerous females inhabiting $P$. auritula was significantly higher than the fecundity of those occupying $C$. atratum and $M$. nodulosa shells. In the laboratory, males showed preference for higher shells following the pattern recorded in the field. According to CHILDRESS (1972), this male pattern is related to the capacity to predict their growth and obtain success during the copulation process.

In relation to shell size, C. atratum was more adequate when compared to M. nodulosa. Stramonita haemastoma, which is heavier and with higher internal volume, favors the occupation by males that search higher shells. Tegula viridula has a distinct architecture (circular aperture and oval shape) from the other shells, that are preferred in lower percentage by hermit crabs. In this respect, we may infer that $P$. tortugae showed a pattern of preference during the shell selection and that the choice varied between the sexes. In the experiment of shells size, males preferred heavier shells whereas females selected for the shape of the shell, including characteristics such as the aperture and the internal volume, what are probably related to the growth and offspring guarantee, respectively.

In relation to the shell type experiments, $P$. tortugae showed a preference for $L$. nassa and C. atratum, differing from the results obtained in the field, when the present species was encountered occupying shells that were possibly more available, but not adequate. Considering that $P$. tortugae showed a plasticity and variability in the shell occupation pattern in Anchieta Island (MANTELATTO \& DOMINCIANO, 2002), we may infer that $P$. tortugae might be constantly searching for adequate shells, but this shell utilization pattern may be strongly associated with the availability of shells in the area (that is considered as a high potential site for gastropod species; Mantelatto \& Meireles, 2004), the size and the reproductive condition of individuals.

Acknowledgments. To FAPESP (Grant \# 98/07454-5) for financial support during sampling work and to CAPES for a Master's fellowship to the senior author. To Secretaria do Meio Ambiente do Estado de São Paulo, IBAMA and Parque Estadual da Ilha Anchieta for permission during sampling work and to Curso de Pós-Graduação em Ciências, Área Biologia Comparada (FFCLRP/USP) for assistance. To Andrea Meireles, Renata Biagi and Ronaldo Christofoletti (Laboratório de Bioecologia e Sistemática de Crustáceos, FFCLRP/ USP) for their help during field collection, laboratory experiments and suggestions on an early draft of the manuscript.

\section{REFERENCES}

Bertness, M. D. 1980. Shell preference and utilization patterns in litoral hermit crabs of the bay of Panama. Journal of Experimental Marine Biology and Ecology, Amsterdam, 48:1-16

Blackstone, N. W. 1984. The effects of history on the shell preference of the hermit crab Pagurus longicarpus (Say). Journal of Experimental Marine Biology and Ecology, Amsterdam,
81:225-234.

Childress, J. R. 1972. Behavioral ecology and fitness theory in a tropical hermit crab. Ecology, Washington, 53:960-964.

Elwood, R. W. \& NeIL, S. J. 1992. Assessments and decisions: a study of information gathering by hermit crabs. London, Chapman \& Hall. 192p.

Fotheringham, N. 1976. Hermit crab shells as a limiting resource (Decapoda, Paguridae). Crustaceana, Leiden, 31(2):193-199.

Garcia, R. B. \& Mantelatto, F. L. M. 2001. Shell selection by the tropical hermit crab Calcinus tibicen (Herbst, 1791) (Anomura, Diogenidae) from southern Brazil. Journal of Experimental Marine Biology and Ecology, Amsterdam, 265:1-14.

HazLetT, B. A. 1996. Recent experience and the shell-size preference of hermit crabs. Marine and Freshwater Behaviour and Physiology, Melbourne, 28:177-182.

Mantelatto, F. L. M. \& Dominciano, L. C. C. 2002. Pattern of shell utilization by the hermit crab Paguristes tortugae (Diogenidae) from Anchieta Island, southern Brazil. Scientia Marina, Barcelona, 66(3):265-272.

Mantelatto, F. L. M. \& Garcia, R. B. 2002. Hermit crab fauna from the infralittoral zone of Anchieta Island (Ubatuba, Brazil). In Briones, E. E. \& Alvarez, F. eds. Modern approaches to the study of Crustacea. New York, Kluwer Academic/Plenum. p 137-144

Mantelatto, F. L. M. \& Meireles, A. L. 2004. The importance of shell occupation and shell availability clustering in the hermit crab Pagurus brevidactylus (Paguridae) population from Southern Atlantic. Bulletin of Marine Science, Miami, 75(2):217-224.

Mantelatto, F. L. M. \& Sousa, L. M. 2000. Population biology of the Atlantic hermit crab Paguristes tortugae (Anomura, Diogenidae) from Anchieta Island, Ubatuba, Brazil. Nauplius, Botucatu, 8(2):185-193

Mantelatto, F. L. M.; Alarcon, V. F. \& Garcia, R. B. 2002. Egg production strategies of the tropical hermit crab Paguristes tortugae from Brazil. Journal of Crustacean Biology, San Antonio, 22(2):390-397.

Mantelatto, F. L. M.; Garcia, R. B. et al. 2001. On a record of Dardanus venosus (H. Milne Edwards) (Crustacea, Anomura) from the São Paulo State, Brazil. Revista Brasileira de Zoologia, Curitiba, 18(1):71-73.

Martinelli, J. M. \& Mantelatto, F. L. M. 1999. Shell utilization by the hermit crab Loxopagurus loxochelis (Diogenidae) in Ubatuba Bay, Brazil. In: Schram, F. R. \& Vaupel Klein, J. C. eds. Crustaceans and the biodiversity crisis. Leiden, Brill. $p$ 719-731

Melo, G. A. S. 1999. Manual de identificação dos Crustacea Decapoda do litoral brasileiro: Anomura, Thalassinidea, Palinuridea e Astacidea. São Paulo, Plêiade. 551p.

OHMORI, H.; WADA, S. et al. 1995. Effects of body size and shell availability on the shell utilization pattern of the hermit crab Pagurus filholi (Anomura: Paguridae). Crustacean Research, Nara, 24:85-92.

Provenzano, A. J., JR. 1978. Larval development of the hermit crab Paguristes spinipes Milne-Edwards, 1880 (Decapoda, Diogenidae) reared in laboratory. Bulletin of Marine Science, Miami, 28(3):512-526.

Reddy, T. \& Bisewar, R. 1993. Patterns of shell utilization in two sympatric species of hermit crabs from the Natal coast (Decapoda, Anomura, Diogenidae). Crustaceana, Leiden, 65(1):13-24

ReEse, E. S. 1962. Shell selection behavior of hermit crabs. Animal Behaviour, London, 10:347-360.

Rios, E. C. 1994. Seashells of Brazil. Rio Grande, Instituto Acqua, Museu Oceanográfico de Rio Grande, Universidade de Rio Grande. 368p.

Siu, B. F. C. \& Lee, S. Y. 1992. Shell preference and utilization pattern in two hermit crabs, Pagurus trigonocheirus (Stimpson) and Clibanarius bimaculatus (De Haan), on a sheltered rocky shore in Hong Kong. Asian Marine Biology, Hong Kong, 9:205-216.

Zar, J. H. 1996. Biostatistical Analysis. New Jersey, PrenticeHall. $907 \mathrm{p}$ 